\title{
Conceptualizing patterns in the dynamics of emerging technologies: The case of biotechnology developments in the Netherlands
}

\author{
Tessa van der Valk*, Ellen H.M. Moors, Marius T.H. Meeus \\ Department of Innovation Studies, Copernicus Institute for Sustainable Development and Innovation, Utrecht University, Heidelberglaan 2 , \\ 3508 TC Utrecht, The Netherlands
}

\begin{abstract}
The major contribution of this study lies in the development of a methodology for studying patterns of dynamics of emerging technologies. Our main research question includes: How can patterns of technology dynamics of emerging technologies be conceptualized? And more specifically to the Dutch biotech case: Which patterns of technology dynamics could be discerned at Dutch dedicated life sciences firms (DDLSFS)? We develop a new approach for conceptualizing patterns of technology dynamics, using an 'opportunity matrix' as the starting point and presenting these patterns by network visualization. We illustrate this new conceptualization by an exemplary case study of emerging biotechnology developments in the Dutch/life sciences sector. Our results show a growing diversity within subsequent populations of newly founded firms over time. Individual newly founded firms were shown to be mainly specialists, working on one technological subfield.
\end{abstract}

(C) 2008 Elsevier Ltd. All rights reserved.

Keywords: Technology dynamics; Emerging technology; Opportunity matrix; Dutch life sciences sector

\section{Introduction}

Emerging technologies in high-technology, knowledgebased sectors, such as biotechnology and nanotechnology, are characterized by rapid development in terms of significance and development rate of new ideas and technologies. A gradually broadening range of scientific and technological fields is included, which keep changing as science and technology progress over time. There are high expectations, but also many uncertainties whether these expectations will be realized (Hopkins et al., 2007). According to Pisano (2006), the performance of the current biotech business is disappointing as not many new drugs have hit the market and the expected breakthrough in research and development $(\mathrm{R} \& \mathrm{D})$ productivity has yet to materialise. Greater emphasis on intergration and long-term learning rather than shorter-term IPR focus is necessary (Pisano, 2006). Prior to any attempt to steer the

\footnotetext{
${ }^{*}$ Corresponding author. Tel.: + 31302531625 ; fax: + 31302532746 .

E-mail address: tessa.vandervalk@tno.nl (T. van der Valk).
}

future direction of emerging technological developments using policy measures, developments that have occurred so far need to be explicated. In this paper, we examine technology dynamics generated by Dutch dedicated life sciences firms (DDLSFs).

To gain insight into technology dynamics, patent data have been a regular source of information (see for instance (Duysters and Hagedoorn, 1998; Malerba and Orsenigo, 1999; Breschi et al., 2003; Saviotti et al., 2005; Zhang et al., 2007; Quintana-Garcia and Benavides-Velasco, 2008). One of the advantages of the use of patents in studying technological developments over time is that they can be easily analysed as a temporal sequence using either the date of application, publication or granting. However, in emerging technological fields the applicability of patent data for the analysis of technology dynamics is questionable. First of all, the firms active in such a field and therefore contributing to technological developments are generally young and small firms. Many of these firms do not have patents yet, to some extent due to high costs and difficulties in protecting the patent when infringement 
occurs (Lemarié et al., 2000). Secondly, many biotechnology firms are spin-offs from research institutes applying knowledge that has already been patented by these research institutes, and these patents cannot always be traced back to the firm. This particular situation is not unique for the Dutch life sciences population, but may apply to all technological fields in which start-ups are considered to contribute significantly to technological change. Instead of applying patent analysis, we have therefore conducted the analysis of technology dynamics by focussing on technologies in use, as was also done by Lemarié et al. (2000). As the usefulness of patent data is limited, focussing on technologies in use can be expected to provide a more elaborate overview of the actual technological developments. In order to analyse the dynamics of technologies in use by start-ups founded from 2000 to 2004, we use the year of founding of these firms. Due to their relatively limited age these firms are not likely to have completely changed their technology portfolio since founding. This will be further elaborated on in Section 3.

In emerging technological fields, demand is unclear or not articulated yet, reducing the applicability of diffusion research. A fruitful approach that has been applied to emerging technologies is the socio-cognitive and institutional approach (Bijker and Law, 1992; Garud and Rappa, 1994; Van de Ven et al., 1999; Rao and Singh, 2001). These studies have provided in-depth analyses of ways in which a specific invention can evolve in laboratories and new business ventures, and very often they report shifting evaluation criteria as to the function and quality of inventions, even in short time periods. These studies show how volatile further development of an invention is. As opposed to the cases of specific inventions addressed in these studies, this study aims to address technology development at a much more general level. By focussing on biotechnology-related developments driven by the population of DDLSFs we are able to unravel patterns of technology dynamics of an emerging technological field, as well as show how the founding of new firms has generated these patterns. Overall, this implies a broader perspective on technology dynamics, complementing the in-depth studies of individual inventions referred to above. Building on earlier work on technological regimes we will advance a set of concepts and measures that enable a systematic analysis of patterns of technology dynamics in emerging technological fields. From the technological regime literature (Nelson and Winter, 1982; Malerba and Orsenigo, 1996; Breschi et al., 2003) we derive the notion of technological opportunities, and from the population ecology literature the notion of the founding of firms over time. As opposed to most of these studies our key indicators are not patents, but technologies in use, and not sectors, but foundings of firms within a sector.

The central research question of this paper then becomes:

How can patterns of technology dynamics of emerging technologies be conceptualized in general? And more specifically with respect to the case of Dutch dedicated life sciences firms: Which patterns of technology dynamics could be discerned at Dutch dedicated life sciences firms? In answering this latter research question, we focus on DDLSFs that have been founded in the period 2000-2004. These central research questions issue several more specific research questions examined in this paper:

(1) Which technological fields can be discerned in modern biotechnology, and how can these be classified?

(2) Which patterns in the development of the technological diversity of the population of newly founded firms could be discerned for subsequent annual populations of these newly founded firms?

(3) To what extent are Dutch dedicated life sciences firms, newly founded in the period 2000-2004 specialists, focussing on one specific technological (sub)field, and to what extent do they combine various technological fields?

Recently, several studies have focussed on organizational aspects and their dynamics with regard to high-technology firms, especially where firms working in biotechnology are concerned (Bigliardi et al., 2005; Nosella et al., 2005; Terziovski and Morgan, 2006; Hall and Bagchi-Sen, 2007; Willemstein et al., 2007; Aharonson et al., 2008). In such studies, the technologies focussed on by these firms are left implicit, and attention is primarily given to organizational aspects of innovation processes. For example, in the process model of 'Biotech innovation management' as presented by Khilji et al. (2006), 'science and technology' is proposed to be the starting point of the innovation process, whereas little attention is paid to the contents of this 'science and technology'. However, as Kash and Rycroft (2002, p. 582) state, "it is the simultaneous evolution of technology and organizations that creates novelty and variety in technological products, processes and in the networks themselves." This paper aims to complement such studies focussing on organizational dynamics by unravelling technology dynamics.

In order to take the diversity of technological subfields within biotechnology into account, we do not focus on a single, specific population of firms, e.g. tissue engineering firms only, but we study whether individual technological subfields become more prominent compared to others over time. If this is the case, there could be a collective direction in which this technological field develops. If not, firms are mostly niche players.

Furthermore, this paper addresses technological combinations made by individual firms across the opportunity set. This is important because other researches have shown how dominant the initial technologies of firms are in determining future developments. Lemarié et al. (2000, p. 9) show that the technologies in use by a sample of UK, German and French biotechnology firms could be traced to their year of founding. The internal renewal of technologies 
is thus not the main driver of technology development, but the founding of new firms is. For this reason it is interesting to study whether, and if so, how many, firms already combine technologies at founding. One might argue that the more combinations of technologies are made by firms across a set of technological opportunities, the larger the innovation opportunities in that population. As indicated by McKelvey et al. (2004), the development of new knowledge and technologies involves ongoing, complex, dynamic processes within society and these affect, in turn, the development of innovation opportunities. Focussing on the technological opportunities and patterns of technology dynamics in biotechnology firms might shed light on ways to better organize vertical integration, complement crossdisciplinary research projects, and share inventions with research institutes, which, according to Pisano (2006), are strategies to overcome the current difficulties in the biotech sector. The policy relevance of this study derives from policy debates in the EU concerning emerging technologies such as biotechnology. These developments started much earlier in the UK, France and Germany than in the Netherlands. Only in the late 1990s, biotechnology was identified by the Dutch government as an important enabling technology for the development of a national knowledge-based economy, which is regarded as a prerequisite for sustaining societal wealth and welfare in the Netherlands in the near future. An analysis of the Ministry of Economic Affairs carried out in 1998 showed that the Dutch biopharmaceutical sector was lagging behind sectors of neighbouring countries, the main barriers being that Dutch knowledge institutes lacked a business culture (Ministry of Economic Affairs, 1999). The results of scientific research were seldom commercialized. There was not enough venture capital available for start-ups and there was a shortage of facilities, such as office and laboratory space (Ministry of Economic Affairs, 1999). From the year 2000 onwards, possibly stimulated by government initiatives that started in these years such as the BioPartner Network programme, opportunities deriving from developments in modern biotechnology have led to the founding of 109 new firms focussing on products and processes based on these developments, and related supporting technologies (BioPartner, 2005). These firms are referred to as dedicated life sciences start-ups. In this research, we study the technologies used by these firms and relate these to common technological fields in biotechnology.

Nowadays, the Dutch life sciences sector is still in an early stage of development and consists of about 160 primarily small, privately held, often loss-making, entrepreneurial firms. Compared to other European populations of life sciences firms the Dutch firms are particularly young. Overall, the number of firms is similar to the numbers active in countries of comparable size, such as Denmark and Belgium (Critical I, 2006). These start-ups mostly began as spin-offs from Dutch academic research groups trying to commercialize new research findings in the biotechnological field. It is expected that the surviving start-up firms will be able to contribute to the development of a new high-technology, knowledge-based industry within the Netherlands.

To summarize, this paper aims to develop a new method for unravelling technology dynamics, and applies this method to the case of biotechnology developments in the Netherlands. Section 2 will present some theoretical notions on concepts of technology dynamics, at the population level as well as the level of the firm. The opportunity matrix will be introduced, leading to a conceptualization of patterns of technology dynamics. Section 3 will discuss the rapid development of modern biotechnology, and gives a classification of the important science and technological fields in biotechnology developments in general. It will subsequently describe the research methodology applied. Section 4 will present the results. In Section 5, the findings will be discussed. Finally, Section 6 will present the conclusions drawn from these results, as an answer to the central research question stated above.

\section{Theoretical notions on patterns of technology dynamics: towards a new conceptualization}

In population ecology there is a line of work that addresses firm foundings and technology cycles. The research on technological regimes and $\mathrm{r}-\mathrm{to}-\mathrm{K}$ transitions in population ecology comes closest to relating technology development to firm foundings, as is pursued in this study. In emerging technological fields, the population of organizations dedicated to these fields is low at first. The number of organizations increases over time, as specialist firms identify and subsequently exploit 'new resource opportunities' (Baum and Rao, 2004). These specific resource opportunities can be perceived as niches, in which specialist organizations attempt to exploit their relatively narrow knowledge portfolios (Brittain and Freeman, 1980). In biotechnology, these specialist organizations are often founded by scientists (Fuchs and Krauss, 2003). As a population grows, the availability of resources decreases, which reduces chances of survival of specialist firms, and induces the appearance of generalist organizations capable of competing "... on the basis of efficiency for the mass market..." (Baum and Rao, 2004, p. 228). Therefore, emerging technological fields such as biotechnology may be expected to be characterized by an increasing number of small, young, specialist organizations, who fill their own specific technological niche. This population of organizations may then be considered homogenous with regard to the breadth of the technology portfolio of the individual organizations, which is low as their portfolios are specialized, but heterogeneous with regard to the specific content of these portfolios. Such a specialization of firms in biotechnology was also indicated by Pyka and Saviotti (2001), who stress the role of such firms as either translators of new knowledge or 
explorers of this knowledge. Orsenigo et al. (2001, p. 490) refer to these new organizations as 'specialized technology originators.'

Over time, strategies with regard to technology development of successful firms might be imitated (Brittain and Freeman, 1980), but the increasing competition for resources within a specific niche might also induce variation within the growing population over time. When an emerging technology is concerned such issues are yet to be resolved.

To develop an in-depth conceptualization of variation, and to link technology dynamics and founding we adopt one of the elements advanced by Malerba and Orsenigo (1996), namely the opportunity conditions. They relate technological opportunities to the potential of innovation within a specific field (Malerba and Orsenigo, 1996, p. 453). These technological opportunities are not stable over time; on the contrary, their extent and focus change over time, as new technological (sub) fields emerge and others become more established. Moreover, the rate of technological progress "depends on the technological "distance" from limits, both prior and subsequent" (Ayres, 1994, p. 67). Thus, the technological opportunities depend, partly, on non-economic factors and constraints, such as the physical properties of materials, but also on funding for research. Technological change is therefore not a smooth or uniform process in time (Ayres, 1994). Barriers and subsequent breakthroughs punctuate it.

The extent to which the technological opportunities described here are taken up is closely related to the competencies of different actors within the technological field, and these competencies are a source of heterogeneity among these actors (Cantner and Pyka, 1998). On the one hand, opportunities can be utilized by established firms with relatively established technology portfolios. This would possibly require diversification of these technology portfolios. However, the likelihood of diversification, especially into unrelated technological fields, is reduced by the bounded rationality of these established actors (Simon, 1957). Moreover, inertia caused by specialization contributes to the relative stability of the technology portfolios of established firms (McKelvey, 1996; Breschi et al., 2003), also more specifically where firms active in biotechnology are concerned (McKelvey, 1996). On the other hand, especially in high-technology sectors such as biotechnology, newly founded firms have been perceived as the main drivers of technological change and they thus could be perceived as the type of actor most likely to utilize these opportunities for innovation. In practice, established firms have been seen to engage in partnering with these new technology-based firms, this partnering functioning as a mechanism to explore new technological opportunities (Pyka and Saviotti, 2001).

From now on, we make an explicit distinction between the level of a population of firms and the level of an individual firm. We examine technology dynamics at these two intertwined levels of analysis.

\subsection{Technological diversity of the population of newly founded firms}

Adhering to a population-level perspective, we aim to provide insight into general developments of technological fields in Dutch biotechnology. This enables us to examine the development of technological fields over time. Population-level technology dynamics is conceptualized as technological diversity of the population, indicating that in a sector the number of technological fields can change over time, as can the extent to which firms are working in these fields. To qualify the notion of technological diversity, we use the nature of changes in technological diversity. Over time, the technological diversity of a population can either decrease, increase or remain stable. This nature of development in diversity is conceptualized by the notions of convergence ${ }^{1}$ and divergence. We speak of technological convergence when technological diversity decreases over time, and of technological divergence when the technological diversity increases over time.

In order to evaluate developments in the technological diversity of the subsequent populations of newly founded firms, we operationalize this concept using two indicators. On the one hand, we incorporate a factor addressing the quantitative aspect of this diversity, namely a measure of the number of different technological fields that is covered by the population of newly founded firms. On the other hand, we also incorporate a more qualitative aspect of diversity, namely related to the variation in the relative contribution of each of the technological fields. This implies using both the number of different technological fields represented over time as well as a measure for the variation in the prominence of these different technological fields. In this study, we use the standard deviation (SD) of the annual shares of the different fields as a measure of their relative prominence: a standardized way of measuring the deviation from the mean annual share (Wonnacott and Wonnacott, 1990).

Combined, developments in the number of fields and the SDs of the shares of these fields over time give us some insight into the question whether there is some extent of technological convergence, divergence or stability in the population of newly founded firms over time. Our interpretation of the results according to convergence/ divergence/stability is given in Table 1. Possibly counterintuitively, decreases in the SD of annual shares of technological fields indicate technological divergence, as different fields are more equally addressed and technological kernels dissolve. Increases in the SD of annual shares of technological fields addressed are a signal of technological convergence of the population of firms, as the prominence of certain fields compared to others increases, indicating the emergence of technological kernels. On the

\footnotetext{
${ }^{1}$ Other studies have used the notion of technological convergence at the level of multiple integrating industries or technological fields (Duysters and Hagedoorn, 1998; Gambardella and Torrisi, 1998).
} 
other hand, an increase in the number of technological fields addressed is a signal of technological divergence of the population. When combining developments in the number of fields addressed and in the SD of the annual shares, nine different combinations can be of relevance, as shown in Table 1. When developments in the SD of the shares and number of fields have opposing effects on patterns of technology dynamics of the population, we are not able to weigh these effects and determine an overall effect; hence the term 'indeterminate' in Table 1. The trend in the relative share of each subfield at $t_{n}$ as compared to $t_{n-1}$ indicates whether technological kernels emerge with a relatively larger share as compared to other subfields.

These patterns of convergence, divergence or stability are expressed at the level of the population and thus at the level of a technological field in general. In this study, these patterns are composed of patterns initiated at the microlevel, namely by newly founded firms. This implies that shifts in the annual shares of technological fields are initiated at the micro-level by differences in technological positioning of newly founded firms over time. These technological opportunities as perceived by these newly founded firms drive subsequent technological developments within the sector. Therefore, we link these developments in technological fields to technology development within firms, by providing an overview of the different technologies that firms combine. These technology portfolios of firms represent the building blocks that constitute patterns of technology dynamics at the level of the population.

Table 1

Operationalization of patterns of technology dynamics at the level of the population.

\begin{tabular}{llll}
\hline SD(shares) & No. of fields & & \\
\cline { 2 - 4 } & $\uparrow$ & Stable & $\downarrow$ \\
\hline$\uparrow$ & Indeterminate & Convergence & Convergence \\
Stable & Divergence & Stability & Convergence \\
$\downarrow$ & Divergence & Divergence & Indeterminate \\
\hline
\end{tabular}

\subsection{Technology dynamics visualized as movement of subsequent populations of newly founded firms across an opportunity matrix}

The first step in visualizing technology dynamics, at both the level of the firm and the technology, is to construct a so-called opportunity matrix, as given in Fig. 1. The rows and columns of this matrix define the technological subfields within a technology. Technology dynamics visualized in this way is a function of the availability and distribution of knowledge within the population of firms. Each founding of a firm can be filled out in this matrix. A founding of a firm on the diagonal implies that an entrepreneur starts business activities as a specialist. A firm can also combine two or more technological fields at founding and thus be founded based on heterogeneous knowledge. As Levinthal (1998) argues, a major source of opportunities for innovation is 'speciation', i.e. the migration and application of an existing technology to other and new application domains. Although the initial technological shift from one domain to another may be small, the speciation event may trigger a substantially new and divergent trajectory. Moreover, innovation is not necessarily equated with change of a single technology. Rosenberg (1982) addressed the role of complementarities: a particular technology can move forward because of inventions and improvements of other technologies. This is also the case for biotechnology. 'Older' DNA/protein-based technologies are now complemented by genomics-based 'newer' technologies such as bioinformatics and proteomics.

Then, a question that arises is how a population of newly founded firms fills the matrix, and whether they fill mainly diagonal cells of the matrix, or do they also fill off-diagonal cells, and which of the possible combinations of technological fields are prominent. We are also interested in whether these prominent combinations remain prominent over time.

After founding, firms can diversify their technology portfolio, in a related or unrelated manner, which would imply movement of this firm across cells of the opportunity matrix. In this study, we do not empirically address diversification strategies of individual firms over time, as we study newly founded firms.

\begin{tabular}{|l|l|l|l|l|l|l|l|l|l|l|}
\hline & TF1 & TF2 & TF3 & TF4 & TF5 & TF6 & TF7 & TF8 & TF9 & TF10 \\
\hline TF1 & & & & & & & & & & \\
\hline TF2 & & & & & & & & & & \\
\hline TF3 & & & & & & & & & & \\
\hline TF4 & & & & & & & & & & \\
\hline TF5 & & & & & & & & & & \\
\hline TF6 & & & & & & & & & & \\
\hline TF7 & & & & & & & & & & \\
\hline TF8 & & & & & & & & & & \\
\hline TF9 & & & & & & & & & & \\
\hline TF10 & & & & & & & & & & \\
\hline
\end{tabular}

Fig. 1. Opportunity matrix of technology development. 
Whereas an opportunity matrix may be a useful instrument for studying technological change, it also has certain limitations. It enables visualization at, at most, a two-dimensional level. This implies that a firm can be attributed only to two technological fields. In order to overcome this limitation we use network visualization software NetDraw (Borgatti, 2002) to depict the twodimensional opportunity matrix, and generate figures in which the nodes are different technological fields that have been discerned, and linkages between these nodes represent firms that combine knowledge of different fields. A similar methodology was also used by Saviotti et al. (2005), for examining knowledge bases of firms using patents of these firms and their corresponding patent categories.

In the next section, we will start with a description of the development of modern biotechnology and a classification of technological fields within this sector, which could fill the first row and first column of the sketched opportunity matrix. Subsequently, further clarification of the research methodology employed, including the method of collecting the firm-level data on the inclusion of technological fields in their technology portfolios, will be provided.

\section{Development of modern biotechnology, data collection and measurements}

Various generations of technological change could be distinguished following the rise of the biotechnology industry over time (see also Hopkins et al., 2007). Prior to the 1880s, plant extracts had been the most important product source. From 1880 until 1930, physiological chemistry and the extraction of natural products came up, and synthetic organic chemistry became more important. During the 1930-1960s organic chemistry and soil microbiology became the most important scientific fields, with the 1950s being the golden age of synthetic drug discovery (Santos, 2003). From 1953 onwards, based on the discovery of the structure of DNA by Watson and Crick, an era of new biotechnology products and processes began. The developments of recombinant DNA technology and recombinant DNA versions of natural products were very important in the 1970 s and 1980 s, respectively. In 2003 the complete sequence of the human genome had been mapped in the HUGO project, making extensive use of bioinformatics to ease the sequencing procedures. Firms at the forefront of biotechnology research are now concentrating more on the so-called small molecules, designed by bioinformatics, combinatorial chemistry, rational drug design and high-throughput analysis techniques (Gassmann et al., 2004).

Furthermore, Walsh (2005) states that while the focus is now on protein-based biopharmaceutical products, mostly being engineered products, in the future, alternative production and delivery systems will come up, such as transgenic-plant-produced products and non-parenteral delivery routes. In addition, more attention will be given to nucleic-acid-based therapeutics, such as gene therapy, antisense technology, RNA interference technology, genomics-based technologies and stem-cell-based therapies.

\subsection{Towards a refined classification of technological fields in modern biotechnology}

Modern biotechnology is a wide emerging technological area and comprises a broad range of scientific and technological fields. Especially from 1970s onwards, many different fields have been involved, and new technological fields, such as bioinformatics, proteomics and pharmacogenomics have been coming up. In order to analyse the patterns of technology dynamics within modern biotechnology developments, this paper will first develop a refined classification of the discernable technological fields. In order to unravel the precise scientific and technological (sub)specializations within broad technological fields, we are not using the broad IPC-codes involving biotechnology often used in patent studies, such as $\mathrm{C} 07 \mathrm{H}$ (sugars, derivatives of nucleotides, nucleotides, nucleic acids) or $\mathrm{C} 12 \mathrm{~S}$ (processes using enzymes or micro-organisms to liberate, separate or purify pre-existing compounds).

We started with the official OECD classification of biotechnology fields (OECD, 2001), identifying five broad categories (McKelvey et al., 2004): (1) DNA (the coding); (2) proteins and molecules (the functional blocks); (3) cell and tissue culture and engineering; (4) process biotechnology and (5) sub-cellular organisms.

Taking into account all the new developments occurring in the various branches of modern biotechnology, we considered this OECD classification into five technological fields too small to cover all the various biotechnology developments. Based on the work of Campbell et al. (1999), Crommelin and Sindelar (2002), Oosterwijk (2003) and Walsh (2005) on future directions of biopharmaceuticals, we added various scientific and technological fields and subfields to the five OECD categories in order to complement them with more recent insights (see Table 2). As can be observed in Table 2, some of the distinguished technological fields have been divided into subcategories to cover all the important technologies related to the main technological field. For example, the technological field of 'proteins and other molecules' covers five subcategories: synthesis and sequencing of proteins and peptides, isolation and purification of proteins, protein engineering, proteomics, and naturally derived products.

Starting from the classification in 11 main technological fields of biotechnology and the involved subcategories (see Table 2), an innumerable amount of combinations are possible. From a market development perspective, it is interesting to explore which Dutch firms are so-called 'boundary spanners' in the biotechnology business, crossing the borders of their own knowledge and technological field and looking for opportunities to combine the knowledge of different technological fields. Which technological fields are then expected to be combined in practice? We will give some illustrative examples: 
Table 2

Classification of technological fields and subfields in modern biotechnology.

1. DNA/RNA: all the topics on DNA coding, and transcription of DNA into RNA. Subfields:

a. Gene probes, genetic engineering

b. DNA-RNA sequencing/synthesis/amplification/purification

c. Functional and comparative genomics, structural genomics

d. Transgenic animals

e. DNA microarrays and oligonucleotide microarrays

f. Single nucleotide polymorphisms (SNPS)

g. Pharmacogenetics and pharmacogenomics: related to response to drug treatment

h. Oligonucleotides: short segments of DNA

I. Antisense technology/triplex technology

II. Aptamer technology

2. Proteins and other molecules: all the topics on functional peptide and protein blocks. Subfields:

a. Sequencing/synthesis of proteins and peptides

b. Protein isolation and purification

c. Protein engineering

I. Site-directed mutagenesis

II. Enzyme engineering

III. Fusion proteins

IV. Antibody engineering

d. Proteomics

e. Naturally derived products

3. Cell and tissue culture and engineering: all the topics on cell and tissue cultures. Subfields:

a. Cell/tissue culture, cell line development

b. Tissue engineering

c. Cellular fusion

d. Vaccine/immune stimulants

e. Embryo manipulation

4. Process biotechnology: all the topics on bioreactors, fermentation, bioprocessing, bioleaching, biopulping, biobleaching, biodesulphurization, bioremediation and biofiltration.

5. Gene and RNA vectors: all the topics on sub-cellular organisms. Subfields:

a. Gene therapy

b. Viral vectors

c. DNA transfer

6. Bioinformatics and development of tools: including the following subfields:

a. Construction of databases on genomes

b. Modelling complex biological processes, including systems biology

c. Instruments and devices applied to biotechnology

I. Bioinformatics

II. High-throughput screening

III. Combinatorial chemistry

IV. Chiral chemistry

V. 3-D structures engineered proteins (crystallography, NMR, spectroscopy, protein modelling)

7. Nanobiotechnology: applies the tools and processes of nano/ microfabrication to build devices for studying biosystems and applications in drug delivery, diagnostics etc.

8. Glycobiology: synthesis of glycolipids and glycoproteins (carbohydrates and branched oligosaccharides, covalently bonded to lipids and proteins, respectively), important in cell-cell recognition.

9. (Bio)materials: includes material intended to interface with biological
Table 2 (continued)

systems to evaluate, treat, augment or replace any tissue, organ or function of the body. These can be used to make implants, protheses and surgical instruments.

10. Bioassays: test to determine the strength or biological activity of a substance, such as a drug or hormone, by comparing its effects with those of a standard preparation on a culture of living cells or a test organism.

11. Drug targeting: a strategy aiming at the delivery of a compound to a particular tissue of the body.

From a market perspective, it could be argued that the broad technological fields of DNA/RNA handling (category 1) and protein synthesis/sequencing (category 2) are quite different, which could possibly come together by means of new genomics-based technologies such as pharmacogenomics, proteomics and metabolomics.

Synthesis of specific DNA/RNA fragments (category 1) or of specific peptides or other molecules (category 2) is in practice often combined with identification techniques of those fragments or molecules (category 6). This identification then gives possibilities to apply these molecules as antibodies or as vaccines (category 3). In this way, categories 1-3 are also often combined.

Firms exploiting process biotechnology (category 4) often have to deal with enzymes and fermentation processes. These enzymes are proteins or DNA/RNA molecules with a specific catalytic function. The synthesis/sequencing and engineering of these enzymes (proteins/DNA/RNA) fall in category 2 and category 1, respectively. In addition, antibody engineering, fusion proteins (category 2), and cell and tissue engineering, especially vaccine/immune stimulants (category 3) and also viral RNA inhibition (category 1) via immune suppression (category 3), are often combined. .

Bioinformatics could in practice be regarded as a broad enabling technology for more technological (sub)fields (category 6). It is based on knowledge of genomics and proteomics (categories 1 and 2), applying modern IT technologies, building electronic databases of genomes and protein sequences, and computer modelling of biomolecules and biologic systems. Furthermore, bioinformatics firms (category 6) sometimes deliver structural data for potential drug targets to firms developing drug delivery systems (category 11).

To sum up, in order to analyse technology dynamics patterns within modern biotechnology we needed a refined classification of involved technological fields and subfields. A biotechnology classification of 11 main categories and related subcategories of technological fields has been provided. In the following section, the method of data collection will be explained.

\subsection{Research population and data gathering}

The population of firms studied here comprises all of the DDLSFs that were established in the period 2000-2004. 
Criteria for the inclusion of these firms were that they needed to be registered at the Dutch Chamber of Commerce and have life sciences as their core business. The definition of life sciences used here is derived from the BioPartner Network (BioPartner, 2005, p. 188) and refers to "those firms that apply the possibilities of organisms, cell cultures, parts of cells or parts of organisms, in an innovative way for the purpose of industrial production. They may also supply related services, and hardware and software." This definition is somewhat broader than just firms focussing solely on modern biotechnology. In total, 93 firms were included in the study.

In order to provide an overview of technologies focussed on by DDLSFs, these firms were characterized according to their in-house technologies. The data used for this were primarily obtained from the websites of the firm. In a few cases, if no information was available online, the information included in their firm profile in the different BioPartner reports was used (BioPartner, 2003, 2004, 2005). This approach differs from the frequently applied method of patent counting and analysis, as was explained in the introduction.

To be able to take into account the temporal aspect of patterns of technology dynamics, we use the year of founding of the firms. The rationale for using this method of collecting data on technological focus at founding is related to the specific characteristics of the population of firms we study. It has already been shown that in modern biotechnology, technological changes are primarily initiated by the entry of new firms, as opposed to shifts in the technological focus of already existing firms (Lemarié et al., 2000; Pyka and Saviotti, 2001). Moreover, the firms studied here are very young and small firms, each having its own highly specific knowledge on which its existence is based. These factors make it unlikely that their technological focus has already clearly switched to an entirely new focus since founding. We do acknowledge the possibility of shifts in the technological focus of these firms, resulting in a more diversified technology portfolio. However, if such a shift has occurred, it is still expected that the core of this focus has remained similar. It is also more likely that they engage in related diversification, as opposed to unrelated diversification (Deephouse, 1999).

Beforehand, different technological fields were identified based on relevant literature, as has already been explained. The in-house technology portfolios of the firms were compiled at the end of 2005. The internet sites of the firms were studied separately by two researchers, who subsequently attributed the firms to their relevant technological field(s). To validate the results obtained, the two databases compiled in this way were compared and differences were identified, discussed, looked up again and decided upon. Working with the list of technological fields was an iterative process; as the different firms were examined for their technological focus, some categories were combined while others were added. This is considered to be relevant as the objective of this part of the study was to give an overview of technological developments in the Dutch life sciences.

\subsection{Measurements}

As was indicated in Section 2, to measure technological diversity we take into account the number of fields covered by these firms, and the SD of the annual shares of these fields. The SD is used as it represents a standardized way of measuring the deviation from the mean annual share (Wonnacott and Wonnacott, 1990). The first step in determining this SD is to calculate the annual shares of each field, which are the number of firms founded on each specific field in a year divided by the total number of firms founded in a year. Subsequently, the SD of these shares is calculated.

In order to address the extent to which firms combine technological (sub)fields, we have also compiled a distribution based on the shares of firms focussing on a specific number of technological (sub)fields. These shares have been calculated by dividing the number of newly founded firms in a certain period that combine a specific number of technological (sub)fields by the total number of firms founded in that period. We make use of the skewness and kurtosis of the frequency distribution of the firms across the number of fields combined to assess whether this distribution deviates from that of a normally distributed random variable.

To be able to take into account explicitly the way in which technology dynamics at the level of the population are shaped by differences in the technology portfolios of newly founded firms over time, we have used network visualization programme NetDraw (Borgatti, 2002). Firms that were on the diagonal of the opportunity matrix in each year in each field were counted and the annual totals per field were imported into the figures as attributes of the fields, determining their relative size compared to the other fields in a particular year. This methodology is similar to the one used by Saviotti et al. (2005) for visualizing the knowledge bases of firms using patents and their corresponding patent categories. In addition to the method of visualization that was used by Saviotti et al. (2005), we are able to show individual firms within these figures. Furthermore, we show firms working on one main field by adding their numbers as attributes of technological fields.

In the following section, the results will be discussed. We will start with the results concerning patterns of technology dynamics on the level of the population of firms, and subsequently focus on the role of individual firms in the developments of these patterns, using network visualization.

\section{Results}

Table 3 provides an overview of the prominence of the different biotechnology-related technological fields in the 
Table 3

Prominence of different biotechnology-related fields in the Netherlands.

\begin{tabular}{l} 
Technological field \\
\hline 1. DNA/RNA: \\
(a) Gene probes, genetic engineering \\
(b) DNA/RNA sequencing/synthesis/ \\
amplification/purification \\
(c) Functional and comparative genomics, \\
structural genomics \\
(d) Transgenic animals \\
(e) DNA microarrays and oligonucleotide \\
microarrays \\
(f) Single nucleotide polymorphisms (SNPs) \\
(g) Pharmacogenetics and pharmacogenomics: \\
related to response to drug treatment \\
(h) Oligonucleotides: short segments of DNA \\
I. Antisense technology/triplex technology \\
II. Aptamer technology \\
(i) Ribozymes
\end{tabular}

\section{Proteins and other molecules}

(a) Sequencing/synthesis of proteins and peptides 10

(b) Protein isolation and purification

(c) Protein engineering

I. Site-directed mutagenesis

II. Enzyme engineering

III. Fusion proteins

IV. Antibody engineering

(d) Proteomics

(e) Natural products

No. of firms active in the field

17, of which:

5

9

4

0

6

2, of which:

0

0

3. Cell and tissue culture and engineering

(a) Cell/tissue culture, cell line development

(b) Tissue engineering

(c) Cellular fusion

(d) Vaccine/immune stimulants

(e) Embryo manipulation

4. Process biotechnology techniques

5. Gene and RNA vectors
(a) Gene therapy
(b) Viral vectors
(c) DNA transfer

6. Bioinformatics/development of tools

(a) Construction of databases on genomes

(b) Modelling complex biological processes, including systems biology

(c) Instruments, devices applied to biotech

I. Bioinformatics

II. High-throughput screening

III. Combinatorial chemistry

IV. Chiral chemistry

V. 3-D structures engineered proteins

7. Nanobiotechnology

1

8. Glycobiology

0
Table 3 (continued)

\begin{tabular}{ll}
\hline Technological field & $\begin{array}{l}\text { No. of firms active in } \\
\text { the field }\end{array}$ \\
\hline 9. (Bio)materials & 9 \\
10. Bioassays & 12 \\
11. Drug targeting & 9 \\
Total number of firms & 82 out of 93 \\
\hline
\end{tabular}

Netherlands. This table provides results on 82 out of the 93 firms that were originally studied here. This is due to the fact that the technology portfolios of the 11 remaining firms could not be evaluated, because of, for instance, a lack of information in general, or a lack of data on the specific technologies used by these firms. Also, the population of life sciences firms included some clinical research organizations, which will not be taken into account here as these organizations are purely service oriented. It is important to note that a single firm could be attributed to more than one technological fields.

Table 3 shows that the most prominent technological field is proteins and other molecules, within which protein engineering is an important area. Sequencing and synthesis of RNA/DNA as well as proteins and other molecules are also core fields. Twenty-two firms are in some way involved in $R \& D$ in the field of instruments and devices, and 12 in bioassays. No firms seemed to be working specifically on glycobiology. Thus, this field is apparently not focussed on by DDLSFs (yet). In the following sections, technological diversity of the population of newly founded firms will be examined further.

\subsection{Developments in the technological diversity of the population of newly founded firms}

The following figures each provide information on the extent to which different technological fields are covered by the population of life sciences firms in 2004, according to their year of founding. As the primary aim here is to illustrate the methodology applied, we limit ourselves to presenting only the results on all main categories (excluding glycobiology as there are no firms working on this field) and the DNA/RNA subfields. In each figure an additional line is included that represents the total number of life sciences firms founded in that year. The scale of this line is presented as a secondary $y$-axis, on the right side of the figure. The figures make it possible to evaluate whether the technological diversity of the population of newly founded firms has increased, decreased or remained stable over time. As can be observed from Fig. 2, the number of firms founded each year and included in this study first decreases from 2000 to 2002, and increases again thereafter. This 


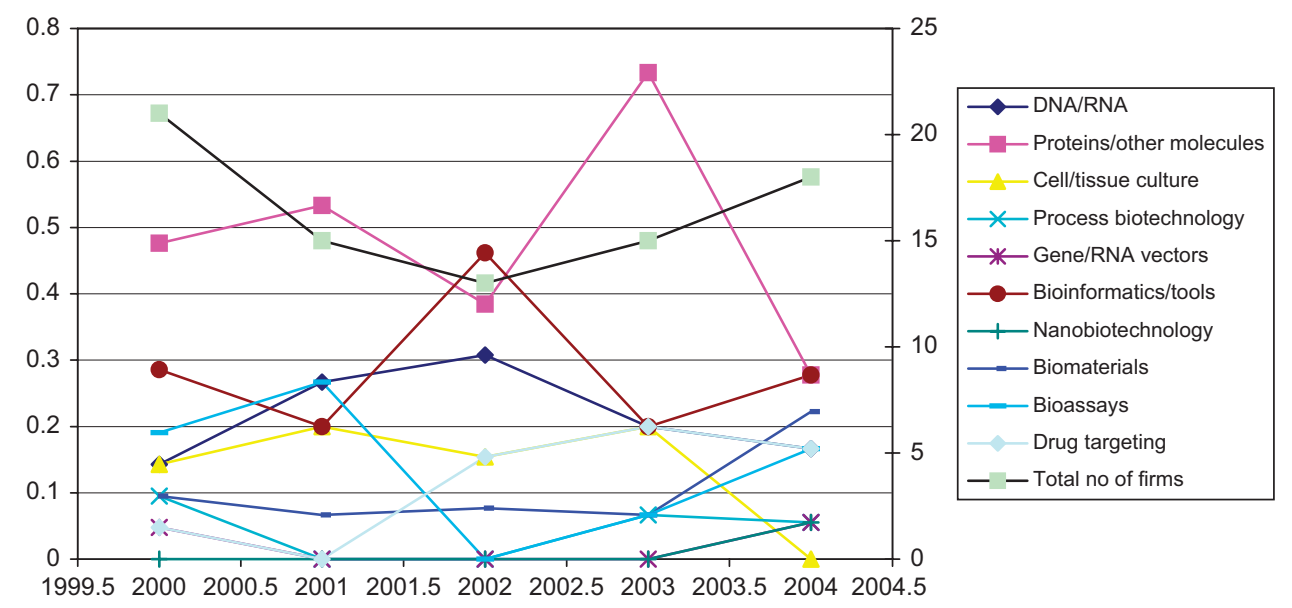

Fig. 2. Annual shares of the different technological fields in the population of newly founded DDLSFs.

figure shows that until 2004, the 'protein' field was relatively prominent compared to the other technological fields that were covered by newly founded firms. Also, in 2002 relatively many firms were founded working on bioinformatics and tools. In 2004, several fields have a similar share, and there does not appear to be a clear technological focus of newly founded firms in the Dutch life sciences. ${ }^{2}$

Fig. 3 provides information on the development of technological diversity of the population of newly founded firms as measured by the number of technological fields and the SD of the annual shares of these technological fields over time. In order to gain an overall insight into the development of these two parameters, linear regression lines have been added to the figure. Studying this figure in detail, it can be concluded that from 2000 to 2001 there is technological convergence, as during this period the number of technological fields addressed decreased while the SD of the shares of these fields increased. For the following year, 2001-2002, the number of fields addressed remained stable, while the SD of the shares decreased slightly. Combined, these developments indicate slight technological convergence. For 2002-2003, we are not able to determine whether the extent of diversity of the population increased or decreased, as developments in the SD of the annual shares and the number of fields covered have opposing effects on this extent. From 2003 onwards, the number of technological fields increased, while the SD of the annual shares decreased, suggesting technological divergence.

The figure shows that developments in the number of fields covered as well as the SD of the shares of these fields were volatile from 2000 to 2004. Overall, with the increase of the number of firms founded each subsequent year, the number of different technological fields on which $\mathrm{R} \& \mathrm{D}$

\footnotetext{
${ }^{2}$ Note that the shares of the different technological fields do not add up to one in each year; after addition they exceed one as a firm could be attributed to multiple technological fields.
}

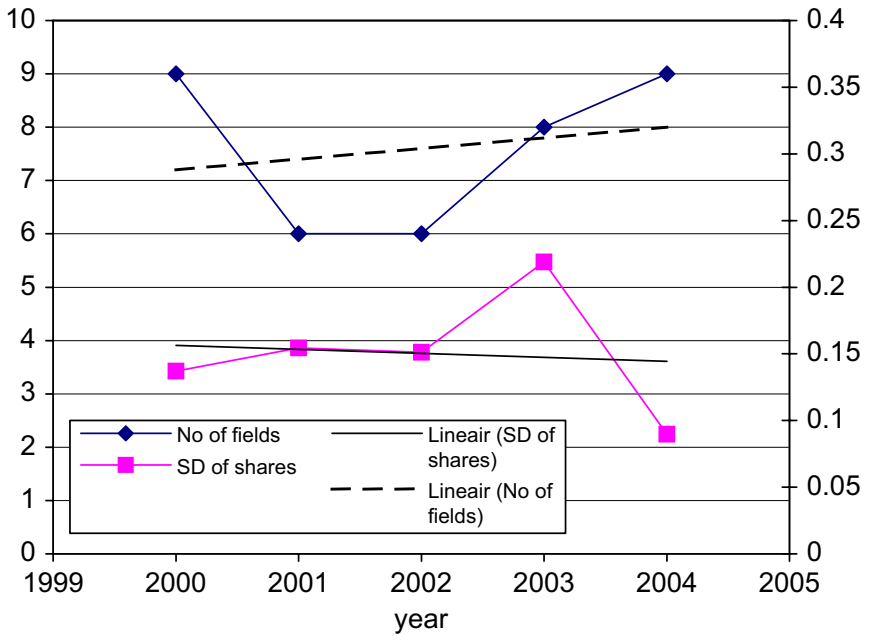

Fig. 3. Technological diversity of newly founded DDLSFs: all main fields $(1-11)$.

activities are conducted also increased, but only slightly. Also, over time, the SD of the shares of these technological fields within the population of firms decreased slightly. These findings indicate that more different technological fields became covered by the population, and the different new firms founded became more equally distributed over these fields over time. This result thus signals that the variation in the focus of R\&D efforts in the Dutch life sciences did not decrease over time; it rather increased slightly. ${ }^{3}$

Figs. 4 and 5 provide an overview of the development of different DNA/RNA-related fields over time, with which it can be derived that the number of technological subfields covered within the main DNA/RNA category fluctuates over time. This development in the number of subfields

\footnotetext{
${ }^{3}$ As the number of values for the number of fields and the SD of the shares of these fields are limited to five, due to our focus on developments from 2000 to 2004, we have not been able to determine the statistical significance of the increase, respectively, decrease in these values over time.
} 


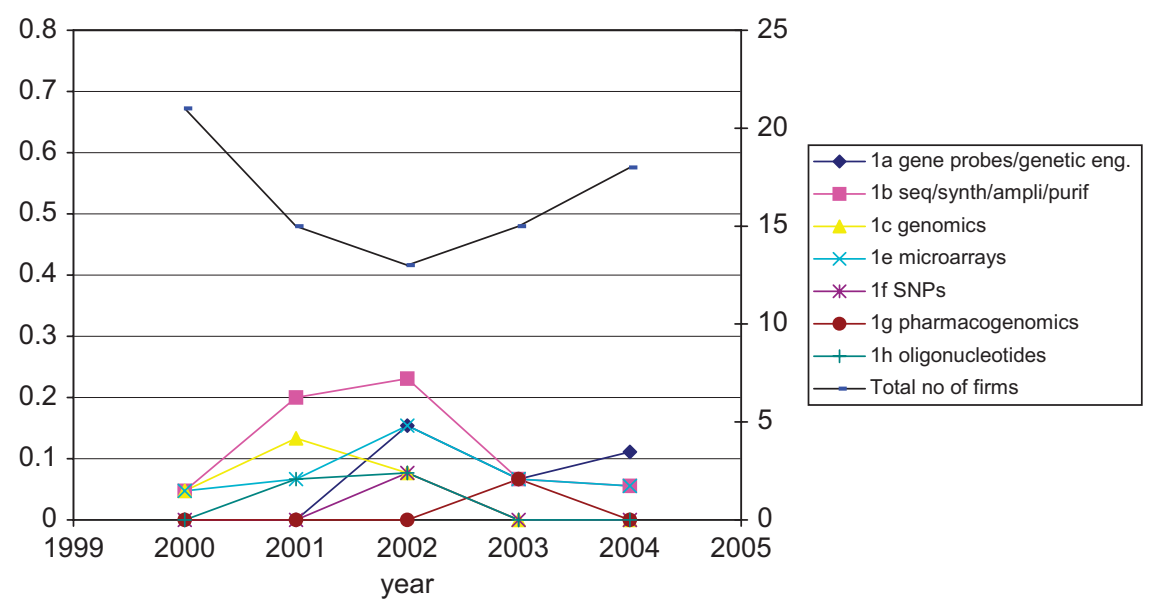

Fig. 4. Annual shares of the different DNA/RNA-based fields in the population of newly founded DDLSFs over time.

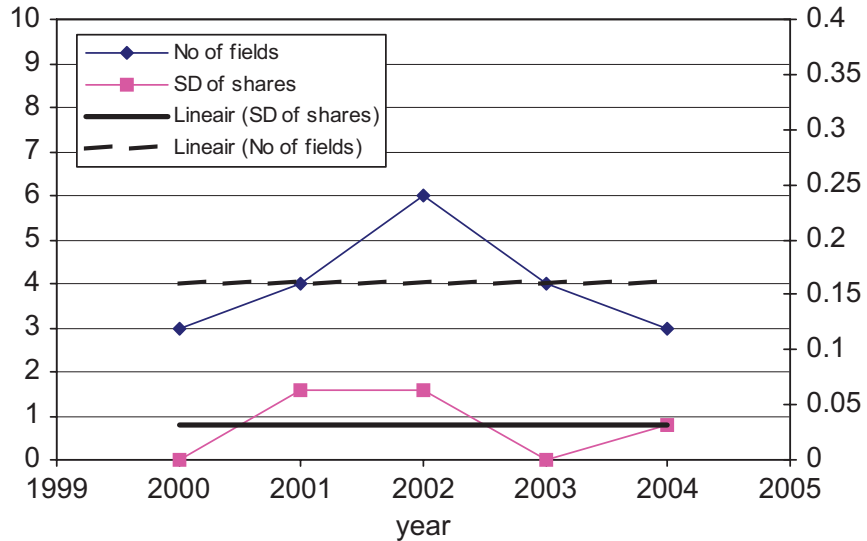

Fig. 5. Technological diversity of newly founded DDLSFs: DNA/RNA fields.

covered does not coincide with the developments in the total number of firms founded each year Sequencing/ synthesis of DNA/RNA was relatively prominent in the first years, but this prominence decreased in the last few years studied. Developments in the shares of the different subfields have been rather similar since 2000 , which is also reflected in the low SDs of the shares of these subfields. Looking more closely, it can be concluded that from 2000 to 2001 , developments in the technological diversity were indeterminate. From 2001 to 2002 the technological diversity of the population increased, as the number of fields addressed increased while the SD of their annual shares was stable. From 2002 to 2003, developments were again indeterminate. From 2003 to 2004 the number of fields addressed decreased while the SD of their annual shares increased, signalling technological convergence. Overall, the technological diversity of newly founded firms in the field of DNA/RNA has been relatively stable, implying that patterns of technology dynamics neither clearly converged nor diverged.

Figs. 2-5 have provided information on developments in the prominence of different technological fields over time, as the population of founded firms changes. Moreover, these figures have provided insight into the extent to which patterns of technology dynamics can be characterized as convergent, divergent or indeterminate. Overall, the results obtained on the main fields (Fig. 3) reflect a slightly growing diversity within the populations of newly founded firms over time, rather than a decrease of this diversity, as there is an increase in the overall number of technological fields covered, while the SD of the annual shares of these fields declines slightly. Developments of the different technological subfields of the main field of DNA/RNA were relatively stable over time.

These patterns of technology dynamics are initiated at the level of the firm by new foundings in the different technological fields. This will be addressed in the following section.

\subsection{Technology dynamics at the level of the firm}

In this section, we will present our results on technology dynamics at the level of the firm. In Table 4 the frequency distribution of the number of technological subfields covered per firm is presented. As can be observed from this table, many firms combine two or more technological subfields in conducting their R\&D. In order to assess the derivation of this distribution from a normally distributed random variable we use its skewness and kurtosis. Overall, these measures indicate a significant deviation from a normal distribution, in which a relatively large number of firms focuses on one or two technological subfields only (skewness $=1.580 ; \mathrm{SD}_{\text {skewness }}=0.266$ ). These findings on the skewness and kurtosis of these distributions indicate that DDLSFs tend to be significantly technologically specialized.

Overall, 38 firms were attributed to one technological subfield only. Fig. 6 provides an overview of the biotechnology-related technological fields these 38 Dutch firms are working in. 'Bioinformatics' and 'proteins and other molecules' are the technological fields these firms typically focus on. Within these two main categories, especially 6c (instruments, devices applied to biotech) is 
Table 4

Frequency distribution of the number of technological subfields per firm.

\begin{tabular}{lc}
\hline No. of technological subfields & Frequency: no. of firms \\
\hline 1.00 & 38 \\
2.00 & 29 \\
3.00 & 8 \\
4.00 & 5 \\
5.00 & 1 \\
6.00 & 1 \\
& \\
Total & 82 \\
\hline
\end{tabular}

dominant as all 12 bioinformatics firms specialize in this subfield.

\subsection{The network visualization figures}

In a further attempt to provide an answer to the third research question, this section addresses the extent to which knowledge related to different technological fields specified is combined by newly founded DDLSFs.

As Table 3 shows, a large share of firms combine two or more technological subfields in conducting their R\&D. In order to gain insight into which fields are combined and how these combinations of fields develop over time, we have compiled figures using the network visualization programme NetDraw (Borgatti, 2002). To enhance the clarity of these figures, the results on different subfields have been aggregated to the corresponding main field. Therefore, in these figures, the nodes in the networks represent the main technological fields that were empirically identified in biotechnology (see Table 2). As our main aim is to illustrate the usefulness of network visualization in unravelling technology dynamics, only the figures of 2000, 2002 and 2004 have been included here. The data that were used to compile these two figures are given in Appendix A. Data on the other annual populations (2001 and 2003) are also included in this appendix.

The total number of firms founded in each year $(N)$ is given directly below the figures. The relative size of each node in each figure was determined by the relative number of firms working only in that main technological field in a particular year. The numbers depicted inside the nodes represent the actual number of firms working only in this main field. This implies that firms attributed to a single node are either specialists or firms combining subfields of that main field. Field 8 (glycobiology) has been omitted from the figures as no firms are working in this field.

The smallest nodes in each figure indicate zero foundings in that corresponding field only in that year. Firms combining knowledge of different technological fields are represented by lines connecting the nodes. A continuous (black) line represents a firm that combines knowledge of the two main technological fields the line connects. Dashed, dotted or other non-continuous lines represent firms combining knowledge of more than two main technological

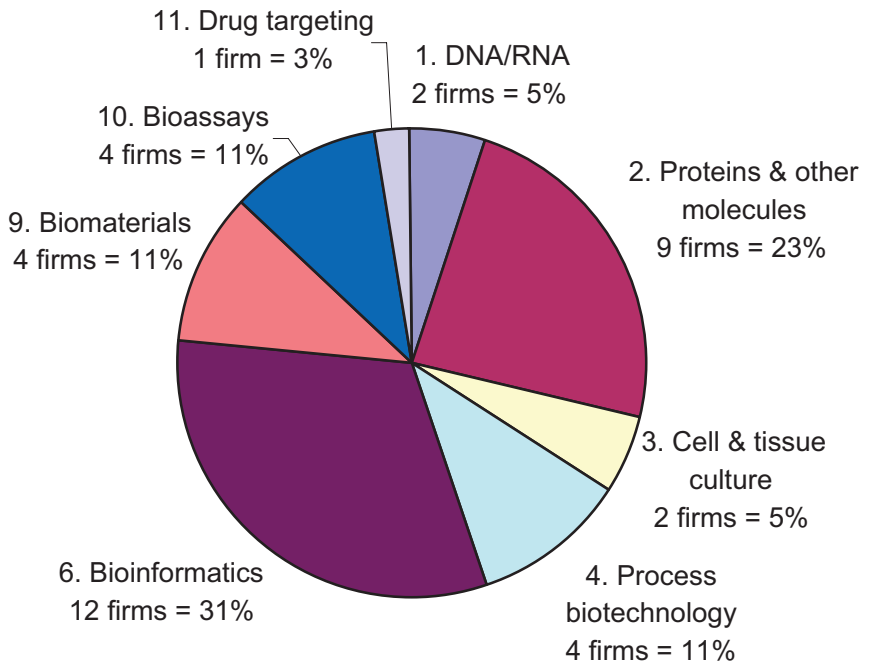

Fig. 6. Distribution of technological fields, for DDLSFs working on one biotech-related subfield $(N=38)$.

fields. Again, the specific fields that are combined by a single firm are those connected by lines that are similarly styled. Being based on this, these figures provide information on the development of the technological fields specified and how these developments are induced by foundings of firms over time, thus from a micro-level perspective. They show how firms, by conducting their R\&D, link different technological fields. For each figure, some examples will be given of the specific technological focus of firms combining knowledge of different fields.

As shown in Fig. 7, in 2000, 13 firms were founded, which work in one main field only (as the number depicted in the nodes adds up to 13). Most of these firms work in field 2 ('proteins and other molecules') or 6 ('instruments'). In total, eight firms combine knowledge of more than one main field. ${ }^{4}$ When examining firms combining knowledge of two or more technological fields, the prominence of field 2 is striking: five out of the eight firms that combine knowledge of different fields employ knowledge belonging to this technological field. Many combinations of different fields are made in 2000. For instance, one firm is engaged in the development of natural molecules, which includes assessing their biological activity using bioassays (combining fields 2 and 10). Another firm provides adjuvants (belonging to field 2) for vaccines (field 3).

In 2002, the number of foundings is 13 , and these firms are almost equally divided between firms working on one main field and firms that combine different fields (seven working on one main field, six firms that combine main fields). As can be derived from Fig. 8, technological field 2 remains prominent when the fields that firms combine are concerned. However, the number of firms working on this

\footnotetext{
${ }^{4}$ Using the explanation given earlier in this section, these eight firms can be identified by counting the number of continuous black lines, each representing a firm combining knowledge of two main fields, and adding to this number the firms represented by differently styled lines. In this case this calculation leads to $6+2=8$.
} 


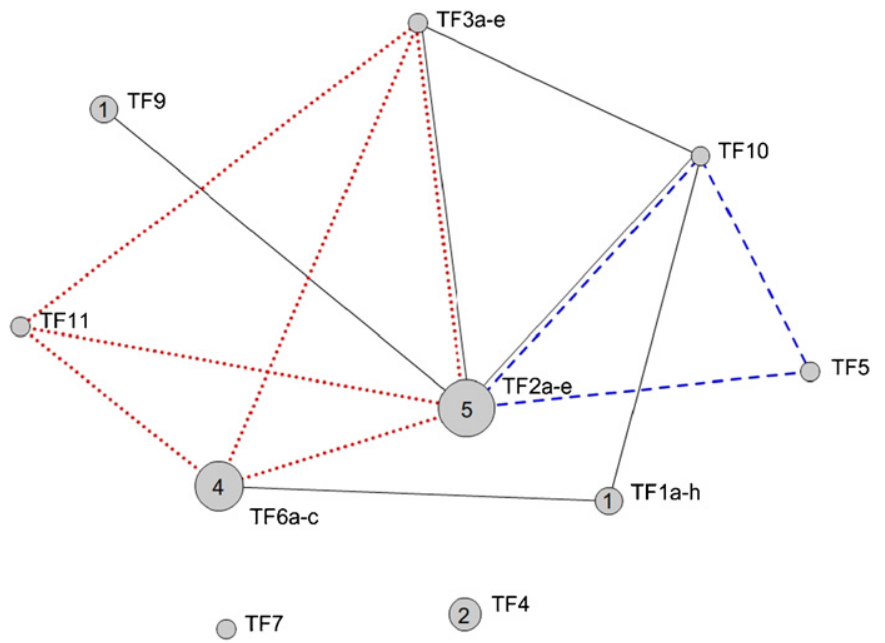

Fig. 7. Technological fields (TFs) addressed by newly founded DDLSFs in $2000\left(N_{2000}=21\right.$; thirteen working in one main field, eight combining main fields).

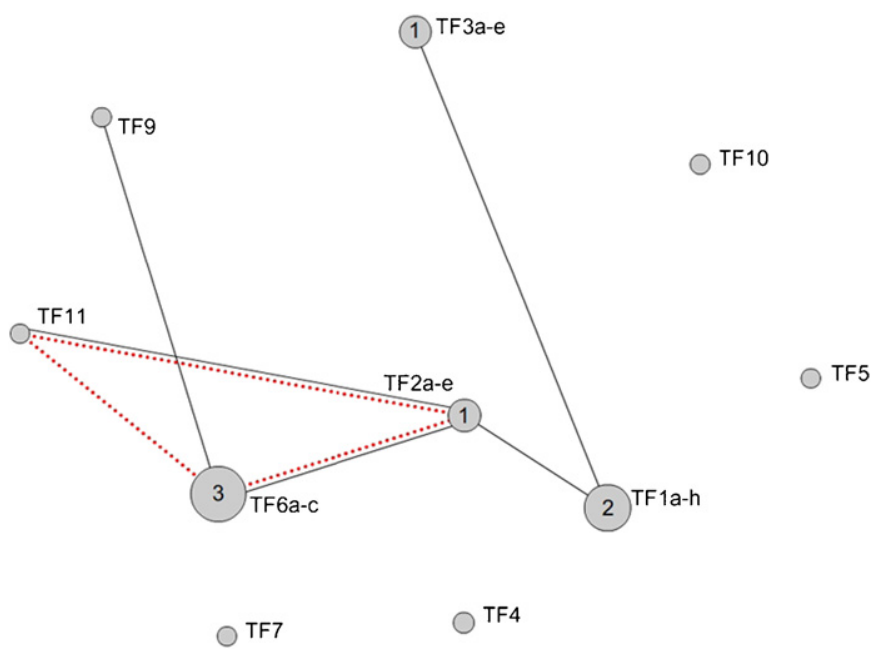

Fig. 8. Technological fields addressed by newly founded DDLSFs in 2002 $\left(N_{2002}=13\right.$; seven working on one main field, six combining main fields).

main field only is low. In this year, field 6 attracts the most specialists and firms combining subfields belonging to the same main field. To illustrate, the firm combining fields 1 and 3 focuses on the inhibition of viral RNA. Both firms combining fields 2 and 11 are focussed on the development of molecules with specific properties (field 2), directed at specific targets (field 11), or in specific formulations (field 11). One of these firms combines this knowledge with knowledge on chiral chemistry (belonging to field 6).

As shown in Fig. 9, in 2004, 12 firms focussed on one main field, while six combined knowledge of two fields or more. Two of these firms that combine main fields focussed on fields 9 ('biomaterials') and 11 ('drug targeting'). These firms are active in the development of drug delivery systems (field 11) using (biodegradable) implants (field 9). Furthermore, 2004 is the first year in which a new firm was established that incorporates nanobiotechnology in its

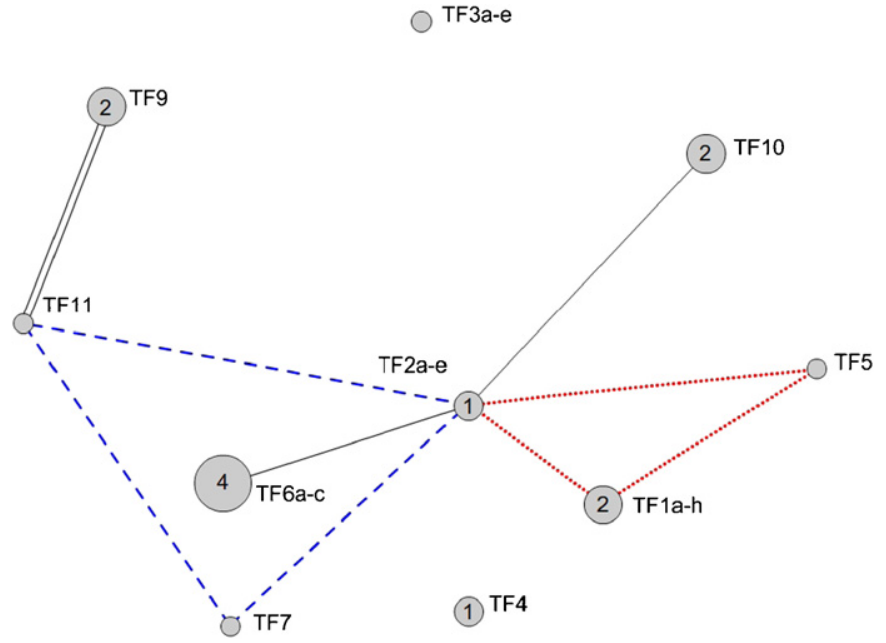

Fig. 9. Technological fields addressed by newly founded DDLSFs in 2004 $\left(N_{2004}=18\right.$; twelve working in one main field, six combining main fields).

technology portfolio. It is also the first year in which a direct connection was made by a firm between fields 1 and 5. This firm focuses on the development of gene (field 1) and protein (field 2) therapeutics, for which it uses DNA transfer (field 5).

\subsection{Overall patterns of technology dynamics: relating the firm level to the population level}

Overall, Figs. 7-9, combined with additional data on the years 2001, 2002 and 2003 given in Appendix A, show that, from the total number of 82 firms, 50 firms are either specialists or combine knowledge of subfields belonging to the same main field, as 50 firms are working on one main field only. The 32 firms that remain are firms that combine knowledge belonging to at least two different main fields that were discerned. Frequently occurring combinations of main fields include fields 2 (proteins and other molecules) and 6 (instruments and tools), 2 and 11 (drug targeting) and 1 (DNA/RNA) and 2. Some other main fields, such as field 4 (process biotechnology), remain rather isolated, which is in accordance with results that were presented earlier, in Fig. 6.

In order to relate the findings presented in this section to the findings presented earlier on developments of the technological diversity, we here address the extent to which firms working in one main field and firms combining fields contribute to the total number of fields covered by firms annually. As is shown in Table 5, the number of different fields covered by specialists is relatively stable over time: six fields in 2004, four in 2002 and five in all other years. The number of fields addressed by firms combining fields founded in each year fluctuated from eight in 2000 to six in 2001, 2002 and 2003, and eight in 2004. The total number of different fields addressed each year, as was also already depicted in Fig. 3, was determined by the extent to 
Table 5

Contribution of DDLSFs working in one main field and firms combining main fields to the total number of fields covered in each year from 2000 to 2004.

\begin{tabular}{|c|c|c|c|c|}
\hline & $\begin{array}{l}\text { No. of fields covered by } \\
\text { DDLSFs working on one } \\
\text { main field }\end{array}$ & $\begin{array}{l}\text { No. of fields covered by } \\
\text { DDLSFs combining } \\
\text { main fields }\end{array}$ & Overlap fields & Total no. of fields covered \\
\hline $2001(N=15)$ & $5(n=10)$ & $6(n=5)$ & 5 & 6 \\
\hline $2002(N=13)$ & $4(n=7)$ & $6(n=6)$ & 4 & 6 \\
\hline $2003(N=15)$ & $5(n=8)$ & $6(n=7)$ & 3 & 8 \\
\hline
\end{tabular}

which firms are working in the same fields, information on which is provided in the fourth column.

As can be derived from this table, in 2001 and 2002, firms working in one main field are working in fields that are also already covered by firms combining fields, as the overlap in fields of these firms equals the number of fields covered by firms working in one field. So, while the overall number of different fields covered in each year to some extent coincided with the number of firms founded in each year, additional variation is generated by the extent to which firms work on the same fields.

From Table 3 it was already derived that 'proteins and other molecules' is the most prominent field in the Dutch dedicated life sciences sector. From Figs. 8 and 9, it can be furthermore derived that this overall prominence is a resultant of the fact that this field is prominent where firms working in one main field as well as firms combining fields are concerned. Based on the figures presented in this section, the decline noticed in the prominence of field 2 in Fig. 2 in the years 2002 and 2004 can be attributed to a decline in the number of firms working in this field only in these years, relative to other years. In 2002 as well as in 2004 , only one firm focussed solely on field 2 .

Taking the network visualization figures into account, it can be stated that the combinations of different fields made by firms over time are volatile. However, there does seem to be a dividing line between fields 6 and 11 on the one hand, and 1, 5 and 10 on the other hand. Fields 2 and 3 are combined with fields of either of these two groups, but there are hardly any direct connections made by firms between the different fields belonging to both groups. Our results show that on the one hand, fields 6 and 11 are combined with 2 and 3 to identify and develop (and in some cases administer to patients) molecules with certain characteristics, whereas fields 1,5 and 10 are combined with fields 2 and 3 in order to enable the development of all sorts of analyses and diagnostics, including analysing the genetic composition of organisms. Firms working on the use of DNA or RNA for disease treatment purposes represent an exception to this general tendency. An example of such a firm is the firm combining fields 1 and 3 in 2002, which focuses on the use of RNA inhibition in the development of therapeutics. The division of biotechnology fields into these groups of fields did not change over time. There do seem to be new areas of application arising over time. For instance, new opportunities arising from developments in the fields of nanobiotechnology have led to the founding of a firm in 2004 combining knowledge from the nanobiotechnology field with the delivery of therapeutics.

\section{Discussion}

Returning to the first part of the central question of this paper, namely: 'How can patterns of technology dynamics of emerging technologies be conceptualized in general?' it can be concluded that the concept of technological diversity as applied in this study provides useful insights into the technological developments over time. On the level of the individual newly founded firm, the 'opportunity matrix' of technology development, combined with network visualization, gives insights into technology development. More specifically, the second part of the research question was: 'Which patterns of technology dynamics could be discerned at Dutch dedicated life sciences firms?' This question was analysed by answering three more specific research questions. These are successively addressed below.

To answer the first more specific research question, namely 'Which technological fields can be discerned in modern biotechnology, and how can these be classified?' we conducted a literature search for relevant technological (sub)fields. This resulted in a list of 1 technological fields, most of which were further specified into subfields. Overall, Dutch policies aimed at stimulating founding of life sciences firms have not triggered focus in the R\&D efforts of these newly founded firms. Rather, in an attempt to answer the second research question, namely 'Which patterns in the development of the technological diversity of the population of newly founded firms could be discerned for subsequent annual populations of these newly founded firms?' we found that there has been an increase in the number of technological fields covered by the newly founded firms and research efforts of firms have become more equally divided over these fields. These two tendencies indicate increasing technological diversity of the annual population of newly founded firms over time. Apparently, forces increasing variation prevail over those of imitation, which is in accordance with population 
ecology studies emphasising variation (Brittain and Freeman, 1980). Further research addressing technology dynamics in the Dutch life sciences over a longer time span would give insight into developments in technological diversity in the long run. Finally, with regard to the third research question specified, i.e. 'To what extent are Dutch dedicated life sciences firms newly founded in the period 2000-2004 specialists, focussing on one specific technological (sub)field, and to what extent do they combine various technological fields?' it can be stated that a relatively high share of firms (38/82) focus on one technological subfield only and are specialists. This finding is in accordance with the notion of Brittain and Freeman (1980), Orsenigo et al. (2001) and Baum and Rao (2004) deriving from population ecology that the emergence of new technological fields induces the founding of specialists, exploring new technological opportunities embedded in specific technological niches. 'Bioinformatics' was found to be a typical specialist field, which is also the case in US biotechnology (Hall and Bagchi-Sen, 2007). Furthermore, 12 firms combined two or more subfields belonging to the same main technological field. Next to these firms, some combinations of main fields made by firms were frequently observed. This could be explained by the fact that these fields are scientifically closely linked together. In this respect, these technological fields can be considered complementary rather than competing, indicating the systemic nature of the technological developments studied here (Barnett, 1990).

\section{Conclusion and implications}

The main contribution of this study is embedded in the conceptualization of patterns of technology dynamics. On the one hand, we have made use of the notions of technological convergence and divergence on the level of subsequent populations of newly founded firms. By assessing both the number of fields covered by these populations of firms over time, and the relative importance of these fields, we have been able to provide insight into the development of an emerging technology over time. On the other hand, we have also introduced the so-called opportunity matrix to gain insight into technology dynamics at the level of the individual firm. Furthermore, in order to visualize these dynamics we have made use of network visualization. Further research could focus on the elaboration of this tool and the coupling to traditional variation, selection and retention models.

This paper aimed to provide insight into a conceptualization of technology dynamics of emerging technologies. Due to the low number of empirical studies on technology dynamics in general, especially those not using patent data, it is difficult to compare our results to other findings on this topic. Although field 2 (proteins and other molecules) was shown to be prominent, results on technological kernels are volatile; there are fluctuations over time. The question that arises then is to what extent some kind of convergence of research efforts in biotechnology in the Netherlands would be desirable to increase the chances of survival of these firms. However, prior research on populations of biotechnology firms in France, Germany and the UK also noted the absence of specialization of these firms on a national level (Lemarié et al., 2000), which could indicate that this is a general aspect of populations of biotechnology firms. This is in accordance with the idea that biotechnology is a global industry (Bartholomew, 1997). As indicated by Ireland and Hine (2007), while firm success also depends on organizational aspects, the quality and newness of the research findings of the firms are eventually decisive. They also substantiate the idea that the inability to bring about change within their organization is an important reason for failure of biotechnology firms (Ireland and Hine, 2007). The precise specialization chosen by an individual firm therefore is decisive for its survival on the long term. The commercial viability of such highly specialized firms, including the DDLSFs, is unclear. Over time they should aim to commercialize their knowledge, as is already apparent in US biotechnology, where a group of firms has reduced its R\&D intensity, and now focuses more on the improvement of its business, for instance by interacting with consumers and gaining access to distribution channels (Hall and Bagchi-Sen, 2007). The increasing importance of alignment with the market may reduce the variety within young populations of biotechnology firms over time, as it may lead to failure of certain organizations.

Taking part in networks of collaboration has been indicated to be crucial for firm survival in biotechnology (see for instance Xia and Roper, 2008). The prominent role of research institutes in the network of DDLSFs is a clear indication of the explorative nature of this network (Van der Valk, 2007; Gilsing and Duysters, 2008). In exploitation, these DDLSFs will need to collaborate with other firms, as is already apparent from the central position of some biotechnology firms in the US network (Powell et al., 2005). The high degree of specialization of DDLSFs may limit their opportunities to engage in joint development (Kim and Higgins, 2007), and make them more fragile.

While the approach provided useful insights into technology dynamics of an emerging technology, it also has some limitations that need to be taken into consideration when conducting further research. First of all, the data used, namely information obtained from websites of the firms studied, could result in biases in the results obtained. More elaborate methods of data collection could be introduced, for instance case study research based on in-depth interviews. Secondly, due to the use of the year of founding as the temporal dimension of technology dynamics, we were not able to trace technological diversification of individual firms over time. By making use of other methods of data collection proposed above it would be possible to gain insight into this diversification. Next to this, the focus on the year of founding might also provide biased results. There might be a discrepancy between the technological focus at the year of founding and the technological fields they are working in, in 2005. 
However, as we have restricted our sample to firms that have been founded since 2000 , we have been able to limit this discrepancy, assuming that firms will stay in a particular technological field for at least a couple of years.

\section{Appendix A. Data used to compile Figs. 8 and 9}

See Fig. A1 and Table A1.

\section{References}

Aharonson, B.S., Baum, J.A.C., Plunket, A., 2008. Inventive and uninventive clusters: the case of Canadian Biotechnology. Research Policy 37, 1108-1131.

Ayres, R.U., 1994. Toward a non-linear dynamics of technological progress. Journal of Economic Behavior and Organization 24, 35-69.

Barnett, W.P., 1990. The organizational ecology of a technological system. Administrative Science Quarterly 35 (1), 31-60.

Bartholomew, S., 1997. National systems of biotechnology innovation: complex interdependencies in a global system. Journal of International Business Studies 28 (2), 241-266.

\begin{tabular}{|c|c|c|c|c|c|c|c|c|c|c|}
\hline & $T F 1_{a-h}$ & TF2 $2_{\text {a-e }}$ & $\mathrm{TF}_{\mathrm{a}-\mathrm{e}}$ & TF4 & TF5 & TF6 ${ }_{\mathrm{a}-\mathrm{c}}$ & TF7 & TF9 & TF10 & TF11 \\
\hline $\mathrm{TF} 1_{\mathrm{a}-\mathrm{h}}$ & $\begin{array}{l}2000: 1 \\
2001: 2 \\
2002: 2 \\
2003: 1 \\
2004: 2\end{array}$ & 2002: 1 & $2002: 1$ & & & $2000: 1$ & & & $2000: 1$ & \\
\hline $\mathrm{TF} 2_{\mathrm{a}-\mathrm{e}}$ & & $\begin{array}{l}2000: 5 \\
2001: 4 \\
2002: 1 \\
2003: 4 \\
2004: 1\end{array}$ & $2000: 1$ & & & $\begin{array}{l}2001: 2 \\
2002: 1 \\
2003: 1 \\
2004: 1\end{array}$ & & $2000: 1$ & $\begin{array}{l}2000: 1 \\
2004: 1\end{array}$ & $\begin{array}{l}2002: 1 \\
2003: 2\end{array}$ \\
\hline $\mathrm{TF} 3_{\mathrm{a}-\mathrm{e}}$ & & & $\begin{array}{l}2001: 1 \\
2002: 1\end{array}$ & & & & & 2001:1 & $2000: 1$ & \\
\hline TF4 & & & & $\begin{array}{l}2000: 2 \\
2003: 1 \\
2004: 1\end{array}$ & & & & & & \\
\hline TF5 & & & & & & & & & & \\
\hline $\mathrm{TF} 6_{\mathrm{a}-\mathrm{c}}$ & & & & & & $\begin{array}{l}2000: 4 \\
2001: 1 \\
2002: 3 \\
2004: 4\end{array}$ & & 2002:1 & & \\
\hline TF7 & & & & & & & & & & \\
\hline TF9 & & & & & & & & $\begin{array}{l}2000: 1 \\
2003: 1 \\
2004: 2\end{array}$ & & $2004: 2$ \\
\hline TF10 & & & & & & & & & $\begin{array}{l}2001: 2 \\
2004: 2\end{array}$ & \\
\hline TF11 & & & & & & & & & & 2003:1 \\
\hline
\end{tabular}

Fig. A1. The opportunity matrix of firms combining two main fields or less $(N=71)$. In this figure, a year of founding is given, followed by the number of firms founded in that year, in that specific field or a combination of two fields. For instance, the '2002:1' stated in the first row and third column means that in 2002, one firm was founded working on a combination of subfields of main fields 1 and 3 .

Table A1

Technological fields of firms combining three or more main fields $(N=11)$.

\begin{tabular}{|c|c|c|c|c|c|c|}
\hline Firm & Field 1 & Field 2 & Field 3 & Field 4 & Field 5 & Founding \\
\hline Firm 1 & 2civ anti body & 5c DNA transfer & 10 bioassays & & & 2000 \\
\hline Firm 2. & $2 \mathrm{c}$ prot engineering & 3a cell line & $6 \mathrm{cv} 3 \mathrm{~d}$ structure & 11 drug delivery & & 2000 \\
\hline Firm 3 & 1e arrays & 2ciii fusion & 10 bioassays & & & 2001 \\
\hline Firm 4 & 1b DNA seq synth & 1c genomics & $2 \mathrm{~d}$ proteomics & $3 \mathrm{~d}$ vaccine & 10 bioassays & 2001 \\
\hline Firm 5 & 2a prot seq/synth & 2cii enzyme & $6 \operatorname{civ}$ chiral & 11 drug delivery & & 2002 \\
\hline Firm 6 & 1a probes/engineering & 2ci site directed & 2ciii fusion prot & 10 bioassays & & 2003 \\
\hline Firm 7 & $2 \mathrm{~d}$ proteomics & $3 \mathrm{~d}$ vaccine & 6cii high throu & & & 2003 \\
\hline Firm 8 & 1b DNA seq synth & 2civ anti body & $3 \mathrm{~d}$ vaccine & & & 2003 \\
\hline Firm 9 & 2 civ anti body & $3 \mathrm{~d}$ vaccine & 6cii high throu & $6 \mathrm{cv} 3 \mathrm{~d}$ structure & & 2003 \\
\hline Firm 10 & 1a probes/engineering & $2 \mathrm{c}$ prot engineering & 5c DNA transfer & & & 2004 \\
\hline Firm 11 & 2 proteins general & 7 nanobiotech & 11 drug delivery & & & 2004 \\
\hline
\end{tabular}


Baum, J.A.C., Rao, H., 2004. Evolutionary dynamics of organizational populations and communities. In: Poole, M.S., Van de Ven, A.H. (Eds.), Handbook of Organizational Change and Innovation. Oxford University Press, New York.

Bigliardi, B., Nosella, A., Verbano, C., 2005. Business models in Italian biotechnology industry: a quantitative analysis. Technovation 25 , 1299-1306.

Bijker, W.E., Law, J., 1992. Shaping Technology, Building Society: Studies in Sociotechnical Change. MIT Press, Cambridge, MA.

BioPartner, 2003. Growth against the tide: the Netherlands Life Sciences Sector report. Biopartner Network.

BioPartner, 2004. The Netherlands Life Sciences Sector report 2004: Moving forward. BioPartner Network.

BioPartner, 2005. The Netherlands Life Sciences Sector report 2005: new challenges ahead. BioPartner Network.

Borgatti, S.P., 2002. NetDraw: Graph Visualization Software. Analytic Technologies, Harvard.

Breschi, S., Lissoni, F., Malerba, F., 2003. Knowledge-relatedness in firm technological diversification. Research Policy 32, 69-87.

Brittain, J.W., Freeman, J.H., 1980. Organizational proliferation and density dependent selection. In: Kimberly, J.R., Miles, R.H. (Eds.), The Organizational Life Cycle: Issues in the Creation, Transformation and Decline of Organizations. Jossey-Bass Publishers, San Francisco, CA.

Campbell, N.A., Reece, J.B., Mitchell, L.G., 1999. Biology. AddisonWesley, Menlo Park, CA.

Cantner, U., Pyka, A., 1998. Technological evolution - an analysis within the knowledge-based approach. Structural Change and Economic Dynamics 9, 85-107.

Critical I, 2006. Biotechnology in Europe: 2006 comparative study. EuropaBio.

Crommelin, D.J.A., Sindelar, R.D., 2002. Pharmaceutical Biotechnology: An Introduction for Pharmacists and Pharmaceutical Scientists. Routledge, London.

Deephouse, 1999. To be different or to be the same? It's a question (and theory) of strategic balance. Strategic Management Journal 20 (2), $147-166$.

Duysters, G.M., Hagedoorn, J., 1998. Technological convergence in the IT industry: the role of strategic technology alliances and technological competencies. International Journal of the Economics of Business 5 (3), 355-368.

Fuchs, G., Krauss, G., 2003. Biotechnology in comparative perspective. In: Fuchs, G. (Ed.), Biotechnology in Comparative Perspective. Routledge, London.

Gambardella, A., Torrisi, S., 1998. Does technological convergence imply convergence in markets? Evidence from the electronics industry. Research Policy 27, 445-463.

Garud, R., Rappa, M.A., 1994. A socio-cognitive model of technology evolution: the case of cochlear implants. Organization Science 5 (3), 344-362.

Gassmann, O., Reepmeyer, G., Von Zedtwitz, M., 2004. Leading Pharmaceutical Innovation. Trends and Drivers for Growth in the Pharmaceutical Industry. Springer, Berlin.

Gilsing, V.A., Duysters, G.M., 2008. Understanding novelty creation in exploration networks: structural and relational embeddedness jointly considered. Technovation 28, 693-708.

Hall, L.A., Bagchi-Sen, S., 2007. An analysis of firm-level innovation strategies in the US biotechnology industry. Technovation 27, 4-14.

Hopkins, M.M., Martin, P.A., Nightingale, P., Kraft, A., Mahdi, S., 2007. The myth of the biotech revolution: an assessment of technological, clinical and organisational change. Research Policy 36, 566-589.

Ireland, D.C., Hine, D., 2007. Harmonizing science and business agendas for growth in new biotechnology firms: case comparisons from five countries. Technovation 27, 676-692.

Kash, D.E., Rycroft, R., 2002. Emerging patterns of complex technological innovation. Technological Forecasting and Social Change 69, 581-606.

Khilji, E., Mroczkowski, T., Bernstein, B., 2006. From invention to innovation: toward developing an integrated innovation model for biotech firms. Journal of Product Innovation Management 23, $528-540$

Kim, J.W., Higgins, M.C., 2007. Where do alliances come from? The effects of upper echelons on alliance formation. Research Policy 36, 499-514.

Lemarié, S., De Looze, M.A., Mangematin, V., 2000. Strategies of European SMEs in biotechnology: the role of size technology and market. Scientometrics 47 (3), 541-560.

Levinthal, D.A., 1998. The slow pace of rapid technological change: gradualism and punctuation in technological change. Industrial and Corporate Change 7 (2), 217-247.

Malerba, F., Orsenigo, L., 1996. Schumpetarian patterns of innovation are technology-specific. Research Policy 25, 451-478.

Malerba, F., Orsenigo, L., 1999. Technological entry, exit and survival: an empirical analysis of patent data. Research Policy 28, 643-660.

McKelvey, M., Rickne, A., Laage-Hellman, J., 2004. The Economic Dynamics of Modern Biotechnology. Edward Elgar, Cheltenham.

McKelvey, M.D., 1996. Evolutionary Innovations: The Business of Biotechnology. Oxford University Press, Oxford.

Ministry of Economic Affairs, 1999. Action Plan Life Sciences 2000-2004. Ministry of Economic Affairs, The Hague.

Nelson, R.R., Winter, S.G., 1982. An Evolutionary Theory of Economic Change. The Belknap Press of Harvard University Press, Cambridge, MA.

Nosella, A., Petroni, G., Verbano, C., 2005. Characteristics of the Italian biotechnology industry and new business models: the initial results of an empirical study. Technovation 25, 841-855.

OECD, 2001. Biotechnology statistics in the OECD member countries: compendium of existing national statistics. STI Working Paper 2001/6, Directorate for Science, Technology and Industry, OECD.

Oosterwijk, H., 2003. In: Sectoral Variations in National Systems of Innovation: The Case of Telecommunication and Modern Biotechnology. Social Sciences. University of Utrecht, Utrecht,, p. 504.

Orsenigo, L., Pammolli, F., Riccaboni, M., 2001. Technological change and network dynamics: lessons for the pharmaceutical industry. Research Policy 30 (3), 485-508.

Pisano, G.P., 2006. Science Business. The Promise, the Reality, and the Future of Biotech. Harvard Business School Press, Boston, MA.

Powell, W.W., Koput, K.W., White, D.R., Owen-Smith, J., 2005. Network dynamics and field evolution: the growth of interorganisational collaboration in the life sciences. American Journal of Sociology 110 (4), 1132-1205.

Pyka, A., Saviotti, P., 2001. Innovation networks in the biotechnologybased sectors. Discussion papers, Institute for Economics, Universitaet Augsburg.

Quintana-Garcia, C., Benavides-Velasco, C.A., 2008. Innovative competence, exploration and exploitation: the influence of technological diversification. Research Policy 37, 492-507.

Rao, H., Singh, J.V., 2001. Organizational speciation as new path creation: institution building activity in the early automobile and biotech industries. In: Garud, R., Karnoe, P. (Eds.), Path Dependence and Creation. Lawrence Erlbaum, London, pp. 243-269.

Rosenberg, N., 1982. Inside the Black Box: Technology and Economics. Cambridge University Press, Cambridge.

Santos, F.M., 2003. The coevolution of firms and their knowledge environment: insights from the pharmaceutical industry. Technological Forecasting and Social Change 70, 687-715.

Saviotti, P., De Looze, M.A., Maupertuis, M.A., 2005. Knowledge dynamics, firm strategy, mergers and acquisitions in the biotechnology-based sectors. Economics of Innovation and New Technology 14 (1), 103-124.

Simon, H.A., 1957. Models of Man: Social and Rational. Wiley, New York.

Terziovski, M., Morgan, J.P., 2006. Management practices and strategies to accelerate the innovation cycle in the biotechnology industry. Technovation 26, 545-552.

Van de Ven, A.H., Polley, D.E., Garud, R., Venkataraman, S., 1999. The Innovation Journey. Oxford University Press, New York/Oxford. 
Van der Valk, T., 2007. Technology dynamics, network dynamics and partnering: the case of Dutch dedicated life sciences firms. Ph.D. Thesis, Netherlands Geographical Studies.

Walsh, G., 2005. Biopharmaceuticals: recent approvals and likely directions. Trends in Biotechnology 23 (11), 553-558.

Willemstein, L., Van der Valk, T., Meeus, M.T.H., 2007. Dynamics in business models: an empirical analysis of medical biotechnology firms in the Netherlands. Technovation 27, 221-232.

Wonnacott, T.H., Wonnacott, R.J., 1990. Introductory Statistics. Wiley, New York

Xia, T., Roper, S., 2008. From capability to connectivity-absorptive capacity and exploratory alliances in biopharmaceutical firms: a US-Europe comparison. Technovation 28, 776-785.

Zhang, J., Baden-Fuller, C., Mangematin, V., 2007. Technological knowledge base, R\&D organization structure and alliance formation: evidence from the biopharmaceutical industry. Research Policy 36, $515-528$.

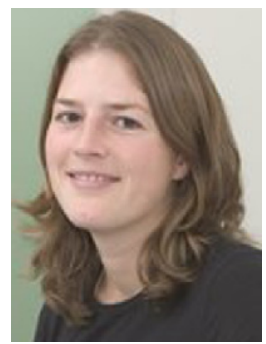

Tessa van der Valk has a master degree in Science and Innovation Management in Medical Biotechnology. She conducted her master thesis at the Dutch Institute for Health and the Environment on the relevance of non-human primate studies for the evaluation of biotechnology-derived pharmaceuticals. In October 2007, she finished her Ph.D. on explaining partnering behaviour of companies active in biotechnology in the Netherlands at the Department of Innovation Studies at Utrecht University. She is currently working at the Innovation Policy group of the Dutch Organization for Applied Scientific Research (TNO).

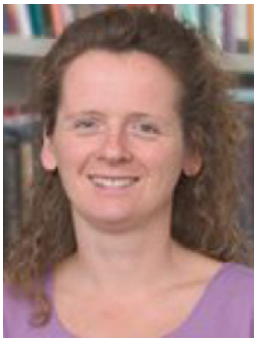

Ellen Moors studied chemistry at the University of Nijmegen. She received a Ph.D. in technology and innovation studies at Delft University of Technology. Since 2001, she is working as an assistant professor at the Department of Innovation Studies, Utrecht University, studying innovation processes in biotechnology developments, focussing on technology dynamics and interaction processes, both from a firm's and an user-producer perspective. She also coordinates the Medical Biotechnology educational track in the bachelor/master programme Science and Innovation Management.

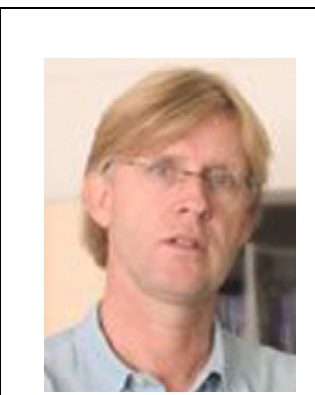

Marius Meeus is a full professor of Strategy, Innovation and Organizational learning at the Department of Organization Studies at Tilburg University. His research focuses on the development and empirical exploration of organization theory applied to the innovative behaviour of firms. He has published in journals such as Research Policy, Technology Analysis and Strategic Management, Organization Studies, etc. His most recent work includes articles and book chapters on theory formation in innovation sciences, the selection-adaptation debate and innovative performance, learning and proximity. 